\title{
Citizenship, Identity and Social History
}

\section{CHARLES TILLY}

With appropriate lags for rethinking, research, writing and publication, international events impinge strongly on the work of social scientists and social historians. The recent popularity of democratization, globalization, international institutions, ethnicity, nationalism, citizenship and identity as research themes stems largely from world affairs: civilianization of major authoritarian regimes in Latin America; dismantling of apartheid in South Africa; collapse of the Soviet Union, the Warsaw Pact and Yugoslavia; ethnic struggles and nationalist claims in Eastern Europe, Asia and Africa; extension of the European Union; rise of East Asian economic powers. Just as African decolonization spurred an enormous literature on modernization and political development, the explosion of claims to political independence on the basis of ethnic distinctness is fomenting a new literature on nationalism.

In the face of bewildering changes, social scientists and social historians look into the past for precedents, parallels, contrasts, causal insights and origins of today's processes. They share with journalists a desire to speak wisely about issues that concern the public. They differ from journalists, on the average, in being more self-revelatory about methods and evidence, integrating their investigations more carefully with previous work on the subject, considering (and combating) contrary interpretations very seriously, and therefore taking much longer to disseminate their results. If the articles in this volume necessarily fall behind today's headlines, at their best they help us anticipate tomorrow's. This introduction aims to provide serviceable synopses of the theoretical problems that motivate our papers, vivid vignettes of essential concepts and irresistible incitement to read the papers themselves.

What is the problem? Even before Eastern Europe broke into a new round of identity-based claim-making entailing new conceptions of citizenship, Western Europe had encountered important.challenges to previous understandings of identity and citizenship. From the 1960s onward, many interpreters and advocates (the distinction blurred) of so-called new social movements concerning peace, environment, gender and related issues had portrayed them as turning away from power politics toward assertions of identity. ${ }^{1}$ The rights and obligations of

${ }^{1}$ For examples, syntheses and critiques, see Robert D. Benford and Scott A. Hunt, "Dramaturgy and Social Movements: The Social Construction and Communication of Power", Sociological Inquiry, 62 (1992), pp. 35-55; Carl Boggs, Social Movements and Political Power. Emerging Forms of Radicalism in the West (Philadelphia, 1986); Tom Brass, "Moral Economists, Subalterns, New Social Movements, and the (Re-) Emergence of a (Post-)Modernized (Middle) Peasant", Journal of Peasant Studies, 18 (1991), pp. 173-

International Review of Social History 40, Supplement 3 (1995), pp. 1-17 
citizenship had aroused new debate as politicians in France, Germany and elsewhere pressed for curtailment of immigration, and as the European Union negotiated protections for expatriates within its precincts. These political currents crossed with a postmodern sensibility featuring (1) skepticism concerning the possibility of verifiable social knowledge, (2) challenge to all assertions of systematic, cumulative social change, and (3) stress on individual consciousness, mediated by language, as the inescapable ultimate social reality.

Faced with changes, doubts and confusions, analysts of political processes have had three choices: join the postmodern juggernaut, combat it with determination, or seek a new synthesis taking into account postmodern challenges to old ideas. Although its authors generally resist postmodern epistemological blandishments, this volume reports work along the third line, work reexamining citizenship and identity in the light of changing conceptions of social history. The papers to follow ask a series of questions:

1 What is citizenship? Where did it come from? How does it vary and change?

2 What has citizenship to do with the identities people deploy in everyday life, including class, race, ethnicity, gender and other identities?

3 How did the strong forms of citizenship we know today come into being?

205; Craig Calhoun, “New Social Movements' of the Early Nineteenth Century", Social Science History, 17 (1993), pp. 385-428; François Chazel (ed.), Action collective et mouvements sociaux (Paris, 1993); Jean L. Cohen and Andrew Arato, Civil Society and Political Theory (Cambridge, 1992); Gita Deneckere, "Norm en deviantie. Een bijdrage over diagnoses van collectieve populaire actie in de Nieuwste Geschiedenis", Tijdschrift voor Sociale Geschiedenis, 16 (1990), pp. 105-127; Jan Willem Duyvendak, Hein-Anton van der Heijden, Ruud Koopmans and Luuk Wijmans (eds), Tussen Verbeelding en Macht. 25 jaar nieuwe sociale bewegingen in Nederland (Amsterdam, 1992); Ron Eyerman and Andrew Jamison, Social Movements. A Cognitive Approach (University Park, Pennsylvania, 1991); Marco Giugni and Hanspeter Kriesi, "Nouveaux mouvements sociaux dans les années '80: Evolution et perspectives", Annuaire suisse de science politique, 30 (1990), pp. 79-100; Marco Giugni and Florence Passy, "Etat et nouveaux mouvements sociaux, comparaison de deux cas contrastés: la France et la Suisse", Revue Suisse de Sociologie, 19 (1993), pp. 545-570; Alberto Melucci, Nomads of the Present. Social Movements and Individual Need in Contemporary Society (Philadelphia, 1989) and "Liberation or Meaning? Social Movements, Culture and Democracy", Development and Change, 23 (1992), pp. 4377; Aldon D. Morris and Carol McClurg Mueller (eds), Frontiers in Social Movement Theory (New Haven, 1992); Thomas Ohlemacher, Brïcken der Mobilisierung. Soziale Relais und persönliche Netzwerke in Bürgerinitiativen gegen militärischen Tiefflug (Wiesbaden, 1993); Dieter Rucht (ed.), Research on Social Movements: The State of the Art in Western Europe and the USA (Frankfurt and Boulder, 1991); Alain Touraine, "An Introduction to the Study of Social Movements", Social Research, 52 (1995), pp. 749-788 and "La Crise de l'Etat-Nation", Revue Internationale de Politique Comparée, 1 (1995), pp. 341-350; E.A. Zdravom'islova, Paradigm'i Zapadnoi Sociologii obsčestvenn'ich dviženii (St Petersburg, 1993). 
Repeatedly we return to T.H. Marshall's influential formulation of half a century ago, which postulated a progression from civic to political to social citizenship, the latter presumably culminating in the full welfare state. ${ }^{2}$ Through no coincidence, Marshall's thesis has attracted renewed attention as throughout the West financially-pressed states have started to restrict, dismantle, or divest entitlements to welfare, health care and unemployment compensation long thought to be ineradicable perquisites of citizenship in Western countries, both capitalist and socialist. Reaction to those changes has driven social historians back to reexamining the experience that Marshall was interpreting, to see where he went wrong, to identify the origins of citizens' entitlements and to reflect on the future of citizenship. In this volume, then, social history responds both to the postmodern challenge and to the reconsideration of T.H. Marshall.

Social history gives us the means to think through how, why, and with what effects citizenship formed, and more generally how struggles over identity have occurred in the past. How so? Social history specializes in the intersection of large processes with small-scale social life; given such a preoccupation, its practitioners necessarily pay attention to changing identities and their political contexts. ${ }^{3}$ True, as critics of social history

2 T.H. Marshall, Citizenship and Social Class (Cambridge, 1950). For explications, critiques, and extensions of Marshall, see J.M. Barbalet, Citizenship (Minneapolis, 1988); Margaret R. Somers, "Citizenship and the Place of the Public Sphere: Law, Community, and Political Culture in the Transition to Democracy", American Sociological Review, 58 (1993), pp. 587-620; Yasemin Nuhoglu Soysal, Limits of Citizenship. Migrants and Postnational Membership in Europe (Chicago, 1994); and Bryan S. Tumer (ed.), Citizenship and Social Theory (Newbury Park, 1993).

${ }^{3}$ For the continued vigor of social history and closely-related enterprises in historical sociology, see Joseba Agirreazkuenaga and Mikel Urquijo (eds), Storia Locale e Microstoria: Due Visione in Confronto (Bilbao, 1993); Lenard R. Berlanstein (ed.), Rethinking Labor History (Urbana, 1993); Peter Burke, History and Social Theory (Ithaca, 1992) and The Art of Conversation (Ithaca, 1993); Julián Casanova, La Historia Social y los Historiadores (Barcelona, 1991); Carlo Ginzburg, Clues, Myths, and the Historical Method (Baltimore, 1986); Carlo Ginzburg and Carlo Poni, "The Name and the Game: Unequal Exchange and the Historiographic Marketplace", in Edward Muir and Guido Ruggiero (eds), Microhistory and the Lost Peoples of Europe (Baltimore, 1991); Don Kalb, "Frameworks of Culture and Class in Historical Research", Theory and Society, 22 (1993), pp. 513-537; Christopher Lloyd, The Structures of History (Oxford, 1993); Erik Monkkonen, "Lessons of Social Science History", Social Science History, 18 (1994), pp. 161168; Ewa Morawska and Willfried Spohn, "'Cultural Pluralism' in Historical Sociology: Recent Theoretical Directions", in Diana Crane (ed.), The Sociology of Culture. Emerging Theoretical Perspectives (Oxford, 1994); Bryan D. Palmer, Descent into Discourse. The Reification of Language and the Writing of Social History (Philadelphia, 1990) and "Critical Theory, Historical Materialism, and the Ostensible End of Marxism: The Poverty of Theory Revisited", International Review of Social History, 38 (1993), pp. 133-162; Germán Rueda Hernanz (ed.), Doce Estudios de Historiografia Contemporánea (Santander, 1991); Dennis Smith, The Rise of Historical Sociology (Philadelphia, 1991); Olivier Zunz (ed.), Reliving the Past. The Worlds of Social History (Chapel Hill, 1985). For more skeptical and postmodern views of the prospects for systematic knowledge of social processes, see Malcolm Ashmore, Robin Wooffitt and Stella Harding (eds), "Humans and Others. The 
have often complained, social historians (myself among them) long inclined to infer interests and identities directly from the everyday organization of production and reproduction. The challenges of idealism and postmodern skepticism have led realist social historians to investigate more seriously than before the political processes that intervene between the routine formation of social relations and interests, on the one hand, and the public articulation of identities and programs, on the other. ${ }^{4}$ (The move in social history has paralleled efforts in economic sociology and institutional economics to examine the embeddedness of ostensibly

Concept of 'Agency' and Its Attribution", special issue of American Behavioral Scientist, 37 (1994); Jonathan Boyarin, "Space, Time, and the Politics of Memory", in Jonathan Boyarin (ed.), Remapping Memory. The Politics of TimeSpace (Minneapolis, 1994); David William Cohen, The Combing of History (Chicago, 1994); Geoffrey Hawthorn, Plausible Worlds. Possibility and Understanding in History and the Social Sciences (Cambridge, 1991); Patrick Joyce, "The End of Social History?", Social History, 20 (1995), pp. 7392, and Jacques Rancière, Les mots de l'histoire. Essai de poétique du savoir (Paris, 1992). 4 Richard Ashcraft, "Liberal Political Theory and Working-Class Radicalism in NineteenthCentury England", Political Theory, 21 (1993), pp. 249-272; John Bohstedt, "The Myth of the Feminine Food Riot: Women as Proto-Citizens in English Community Politics, 1790-1810", in Harriet B. Applewhite and Darline G. Levy (eds), Women and Politics in the Age of the Democratic Revolution (Ann Arbor, 1990); Claus Bjorn, Alexander Grant and Keith J. Stringer (eds), Social and Political Identities in Western History (Copenhagen, 1994); Craig Calhoun, "The Problem of Identity in Collective Action", in Joan Huber (ed.), Macro-Micro Linkages in Sociology (Newbury Park, 1991) and "Nationalism and Ethnicity", Annual Review of Sociology, 19 (1993), pp. 211-239; Gregory Claeys, "The Origins of the Rights of Labor: Republicanism, Commerce, and the Construction of Modern Social Theory in Britain, 1796-1805", Journal of Modern History, 66 (1994), pp. 249-290; Linda Colley, Britons. Forging the Nation 1707-1837 (New Haven, 1992); Harry T. Dickinson, "Popular Loyalism in Britain in the 1790s", in Hellmuth Eckhart (ed.), The Transformation of Political Culture. England and Germany in the Late Eighteenth Century (London, 1990); James Epstein, "Understanding the Cap of Liberty: Symbolic Practice and Social Conflict in Early Nineteenth-Century England", Past and Present, 122 (1989), pp. 75-118 and "The Constitutional Idiom: Radical Reasoning, Rhetoric and Action in Early Nineteenth Century England", Journal of Social History, 23 (1990), pp. 553-574; Michael P. Hanagan, "New Perspectives on Class Formation: Culture, Reproduction, and Agency", Social Science History, 18 (1994), pp. 77-94; Uffe Østergard, "'Denationalizing' National History. The Comparative Study of Nation-States", Culture and History, 9-10 (1991), pp. 9-41 and "Peasants and Danes: The Danish National Identity and Political Culture", Comparative Studies in Society and History, 34 (1992), pp. 3-27; Peter Sahlins, Boundaries. The Making of France and Spain in the Pyrenees (Berkeley, 1989); William H. Sewell, Jr., "A Theory of Structure: Duality, Agency, and Transformation", American Journal of Sociology, 98 (1992), pp. 1-29; Margaret R. Somers, "Narrativity, Narrative Identity, and Social Action: Rethinking English Working-Class Formation", Social Science History, 16 (1992), pp. 591-630; Marc W. Steinberg; "The Dialogue of Struggle: The Contest over Ideological Boundaries in the Case of London Silk Weavers in the Early Nineteenth Century", Social Science History, 18 (1994), pp. 505-542; Sidney Tarrow, Power in Movement (Cambridge, .1994); Charles Tilly, "Social Movements as Historically Specific Clusters of Political Performances", Berkeley Journal of Sociology, 38 (1993-1994), pp. 1-30 and Popular Contention in Great Britain, 1758-1834 (Cambridge, 1995); Mark Traugott, "Barricades as Repertoire: Continuities and Discontinuities in the History of French Contention", Social Science History, 17 (1993), pp. 309-323. 
market-dictated transactions in the complexities of culture and social relations. ${ }^{5}$ ) From that reconsideration has emerged an increasingly relational, cultural, historical and contingent conception of public identities, including the identity of citizenship.

The emerging view is relational in the sense that it locates identities in connections among individuals and groups rather than in the minds of particular persons or of whole populations. It therefore breaks with both the sorts of individualism that have dominated recent analyses of social life: both (1) methodological individualism with its independent, self-contained, self-propelling rational actors and (2) phenomenological individualism with its deep subjectivity as well as its penchant for solipsism. ${ }^{6}$ The emerging view is not only relational but cultural in insisting that social identities rest on shared understandings and their representations. It is historical in calling attention to the path-dependent accretion of memories, understandings and means of action within particular identities. The emerging view, finally, is contingent in that it regards each

' George A. Akerlof, "Gift Exchange and Efficiency Wage Theory: Four Views", American Economic Review Proceedings, 74 (1984), pp. 79-83; James N. Baron and Michael T. Hannan, "The Impact of Economics on Contemporary Sociology", Journal of Economic Literature, 32 (1994), pp. 1111-1146; Glenn R. Carroll and J. Richard Harrison, "On the Historical Efficiency of Competition between Organizational Populations", American Journal of Sociology, 100 (1994), pp. 720-749; Alfred Chandler, "Organizational Capabilities and the Economic History of the Industrial Enterprise", Journal of Economic Perspectives, 6 (1992), pp. 79-100; Ronald Coase, "The Institutional Structure of Production", American Economic Review, 82 (1992), pp. 713-719; Mark Granovetter, "The Sociological and Economic Approaches to Labor Markets", in George Farkas and Paula England (eds), Industries, Firms, and Jobs: Sociological and Economic Approaches (New York, 1988); Mark Granovetter and Charles Tilly, "Inequality and Labor Processes", in Neil J. Smelser (ed.), Handbook of Sociology (Newbury Park, 1988); Alejandro Portes (ed.), The Economic Sociology of Immigration (New York, 1995); Alejandro Portes and Julia Sensenbrenner, "Embeddedness and Immigration: Notes on the Social Determinants of Economic Action", American Journal of Sociology, 98 (1993), pp. 1320-1350; Barbara Reskin and Patricia A. Roos, Job Queues, Gender Queues. Explaining Women's Inroads into Male Occupations (Philadelphia, 1990); Herbert Simon, "Organizations and Markets", Journal of Economic Perspectives, 5 (1991), pp. 25-44; Chris Tilly and Charles Tilly, "Capitalist Work and Labor Markets", in Neil J. Smelser and Richard Swedberg (eds), Handbook of Economic Sociology (New York and Princeton, 1994); Harrison White, "Varieties of Markets", in Barry Wellman and Steven Berkowitz (eds), Social Structures: A Network Approach (Cambridge, 1988); Viviana Zelizer, "The Creation of Domestic Currencies", American Economic Review. Papers and Proceedings, 84 (1994), pp. 138142 and The Social Meaning of Money (New York, 1994).

- Rajeev Bhargava, Individualism in Social Science. Forms and Limits of a Methodology (Oxford, 1992); Pierre Birnbaum and Jean Leca (eds), Sur l'individualisme (Paris, 1987); Daniel Druckman, "Nationalism, Patriotism, and Group Loyalty: A Social Psychological Perspective", Mershon International Studies Review, 38 (1994), pp. 43-68; Seymour Feshbach, "Individual Aggression, National Attachment, and the Search for Peace: Psychological Perspectives", Aggressive Behavior, 13 (1987), pp. 315-325; Michael Hechter (ed.), The Microfoundations of Macrosociology (Philadelphia, 1983); Charles Tilly, "Softcore Solipsism", Labour/Le Travail, 34 (1994), pp. 259-268. 
assertion of identity as a strategic interaction liable to failure or misfiring rather than as a straightforward expression of an actor's attributes. Thus scholars have come to think of citizenship as a set of mutual, contested claims between agents of states and members of socially-constructed categories: genders, races, nationalities and others. ${ }^{7}$

Without pretending to review or synthesize that large accumulating literature, let me lay out a series of concepts that follow from it before proceeding to observations about the interplay of citizenship and identity. The concepts run as follows:

Actor: any set of living bodies (including a single individual) to which human observers attribute coherent consciousness and intention.

'Benedict Anderson, Imagined Communities. Reflections on the Origin and Spread of Nationalism (London, 1991); Adam Ashforth, The Politics of Official Discourse in TwentiethCentury South Africa (Oxford, 1990); Claus Bjøm, Alexander Grant and Keith J. Stringer (eds), Nations, Nationalism and Patriotism in the European Past (Copenhagen, 1994); Jonathan Boyarin (ed.), Remapping Memory. The Politics of TimeSpace (Minneapolis, 1994); Rogers Brubaker, "East European, Soviet, and Post-Soviet Nationalisms: A Framework for Analysis", Research on Democracy and Society, 1 (1993), pp. 353-378 and "Rethinking Nationhood: Nation as Institutionalized Form, Practical Category, Contingent Event", Contention, 4 (1994), pp. 3-14; John Comaroff, "Humanity, Ethnicity, Nationality: Conceptual and Comparative Perspectives on the U.S.S.R.", Theory and Society, 20 (1991), pp. 661-688; Hugh Cunningham, "The Language of Patriotism", History Workshop Journal, 12 (1981), pp. 8-33; Peter Guardino, "Identity and Nationalism in Mexico: Guerrero, 1780-1840", Journal of Historical Sociology, 7 (1994), pp. 314-342; Kemal H. Karpat, "Gli stati balcanici e il nazionalismo: l'immagine e la realtà", Quaderni Storici, 84 (1993), pp. 679-718; Ludger Mees, Entre nación y clase. El nacionalismo vasco y su base social en perspectiva comparativa (Bilbao, 1991); Gérard Noiriel, La tyrannie du National. Le droit d'asile en Europe 1793-1993 (Paris, 1991) and "L'identification des citoyens. Naissance de l'état civil républicain", Genèses, 13 (1993), pp. 3-28; Ann Shola Orloff, "Gender and the Social Rights of Citizenship: The Comparative Analysis of Gender Relations and Welfare States", American Sociological Review, 58 (1993), pp. 303-328; Pierre Rosanvallon, L'Etat en France de 1789 a nos jours (Paris, 1990); Lawrence Rosen, "The Integrity of Cultares", American Behavioral Scientist, 34 (1991), pp. 594-617; Marc Shell, Children of the Earth. Literature, Politics and Nationhood (New York, 1993); Frida Thórarinsdóttir, "National, State and Language. An Invented Unity", Working Paper 188, Center for Studies of Social Change, New School for Social Research (1994); Christian Topalov, "Patriotismes et citoyennetés", Genèses, 3 (1991), pp. 162-176; Dror Wahrman, "Virtual Representation: Parliamentary Reporting and Languages of Class in the 1790s", Past and Present, 136 (1992), pp. 83-113; Alexander Wendt, "Collective Identity Formation and the International State", American Political Science Review, 88 (1994), pp. 384-398. On relational analyses more generally, see Peter S. Bearman, Relations into Rhetorics. Local Elite Social Structure in Norfolk, England, 1540-1640 (New Brunswick, 1993); Maurice Blanc (ed.), Pour une sociologie de la transaction sociale (Paris, 1992); Mustafa Emirbayer and Jeff Goodwin, "Network Analysis, Culture, and the Problem of Agency", American Journal of Sociology, 99 (1994); pp. 1411-1454; Kyriakos M. Kontopoulos, The Logics of Social Structure (Cambridge, 1993); Margaret R. Somers, "The Narrative Constitution of Identity: A Relational and Network Approach", Theory and Society, 23 (1994), pp. 605-650; Harrison White, Ideritity and Control. A Structural Theory of Social Action (Princeton, 1992) and "Where Do Languages Come From? - Switching Talk", Working Paper 202, Center for the Social Sciences, Columbia University, 22 March 1995. 
Category: a set of actors distinguished by a single criterion, simple or complex.

Transaction: a bounded communication between one actor and another.

Tie: a continuing series of transactions to which participants attach shared understandings, memories, forecasts, rights and obligations. Role: a bundle of ties attached to a single actor.

Network: a more or less homogeneous set of ties among three or more actors.

Group: coincidence of a category and a network.

Organization: group in which at least one actor has the right to speak authoritatively for the whole.

Identity: an actor's experience of a category, tie, role, network, group or organization, coupled with a public representation of that experience; the public representation often takes the form of a shared story, a narrative.

The concept "identity" has remained blurred but indispensable in political analysis and social history for three obvious reasons: first, the phenomenon of identity is not private and individual but public and relational; second, it spans the whole range from category to organization; third, any actor deploys multiple identities, at least one per category, tie, role, network, group and organization to which the actor is attached. That others often typify and respond to an actor by singling out one of those multiple identities - race, gender, class, job, religious affiliation, national origin, or something else - by no means establishes the unity, or even the tight connectedness, of those identities. That illness or zealotry occasionally elevates one identity to overwhelming dominance of an actor's consciousness and behavior, furthermore, does not gainsay the prevalence of multiple identities among people who are neither ill nor zealots.

Proponents of phenomenological individualism have often confused themselves with respect to identities by assuming that language entraps individuals, that preexisting presumptions and categories of language provide the filters through which all social experience passes, hence that reliable knowledge of social relations is impossible. Such a view disregards the deeply. interactive character of language itself, its location in constantly-negotiated conversations rather than individual minds. Indeed, language provides a medium for the establishment and renegotiation of identities, seen as an actor's experience of a category, tie, role, network, group or organization, coupled with a public representation of that experience. The narrative offered in such a public representation ordinarily stresses the interplay of social relations and individual traits: we are $\mathrm{Xs}$ by virtue of experiences we share with other Xs in relation to all those (very different) Ys.

In this frame, we begin to see why the word "citizenship" causes confusion. It can refer to a category, to a tie, to a role, or to an identity 
built on one of them, even on several of them. As a category, citizenship designates a set of actors - citizens - distinguished by their shared privileged position vis-à-vis some particular state. As a tie, citizenship identifies an enforceable mutual relation between an actor and state agents. As a role, citizenship includes all of an actor's relations to others that depend on the actor's relation to a particular state. And as an identity, citizenship can refer to the experience and public representation of category, tie or role. Thus Marshall's classic treatment of citizenship identifies it as a set of rights - that is, a special tie with enforcement built in - relating a state to a whole category of persons. Despite citing Marshall directly, Seymour Martin Lipset counters with a categorical definition of citizenship, those people who are included in a given state's circle of full political participation. ${ }^{8}$ True to his usual brilliant ambivalence when confronted with the choice of individualistic and relational analyses, Stein Rokkan balances uneasily between the two views. ${ }^{9}$ No standard definition of citizenship has yet gained scholarly consensus.

Today's dissensus gives us no reason to abandon the search for a useful definition. For theoretical and historical clarity, we should confine the definition of citizenship to a certain kind of tie: a continuing series of transactions between persons and agents of a given state in which each has enforceable rights and obligations uniquely by virtue of (1) the person's membership in an exclusive category, the native-born plus the naturalized and (2) the agent's relation to the state rather than any other authority the agent may enjoy. Citizenship thus forms a special sort of contract. The definition is, of course, ideal-typical, abstracting from particular ties connecting this citizen with that agent. We might recast it in the form "A tie qualifies as citizenship in so far as it entails enforceable rights and obligations based on persons' categorical membership and agents' relation to the state." Citizenship can then range from thin to thick: thin where it entails few transactions, rights and obligations; thick where it occupies a significant share of all transactions, rights and obligations sustained by state agents and people living under their jurisdiction.

Such a definition allows for multiple categories and forms of citizenship within the jurisdiction of the same state, as in the "active" and "passive" citizens the French revolutionary regime distinguished until 1792 or the intricate hierarchy of citizenships the Venetian state established during its years of imperial glory. ${ }^{10}$ Such a definition also permits us to trace

${ }^{8}$ Seymour Martin Lipset, Political Man. The Social Bases of Politics (Garden City, 1960), pp. 55, 84-85, 92-93.

9 Stein Rokkan, Citizens, Elections, Parties. Approaches to the Comparative Study of Processes of Development (Oslo, 1970), pp. 27-28. See Charles Tilly, "Stein Rokkan et les Identités Politiques", Revue Internationale de Politique Comparée, 2 (1995), pp. 27-45. ${ }^{10}$ Isser Woloch, The New Regime. Transformations of the French Civic Order, 1789-1820s (New York, 1994); Frederic C. Lane, Venice, a Maritime Republic (Baltimore, 1973); 
the effects of citizenship on categories, roles and identities without conflating them. While acknowledging its connection to categories, roles and identities, we should recognize citizenship as a kind of tie because such a conceptualization centers attention on state practices and statecitizen interactions. That attention helps us see how struggle and bargaining between expanding states and their subjects created citizenship where it had not previously existed.

People generally build organizations by reshaping and piecing together chunks of existing social structure rather than inventing whole new forms; new configurations entail substantial transaction costs for their creation, implementation, articulation and learning, so simple parsimony gives the advantage to known relations and understandings. In the case of states and their citizenship, gender provides the most pervasive example: the tying of citizenship to military service and presumed economic independence built the system of male-female relations that already prevailed in households, shops and communities directly into the state's own organization. It took more than a century for feminists to mobilize effectively on behalf of redefinitions breaking the sturdilyconstructed 'gender barrier.

States often use other previously-existing ties than gender as bases for forming ties of citizenship or as grounds for exclusion from citizenship. Imputed ethnicity and nationality provide important cases in point. Both ethnic groups and nationalities consist of social categories defined (and distinguished from other social categories) by beliefs concerning shared origins, culture and social relations. Following the old joke "a language is a dialect that has its own army", a nationality is an ethnicity bearing a favored relation to a particular state. Rogers Brubaker has popularized the venerable distinction between jus sanguinis and jus solis, between a principle of descent and a principle of residence, pointing out how the nineteenth-century German state-in-the-making emphasized nationality, descent from certifiable Germans (defined by language and culture) as qualification for citizenship, while the French state remained much more open to the naturalization of residents who had planted themselves sufficiently in French cultural soil. ${ }^{11}$

M.E. Mallett and J.R. Hale, The Military Organization of a Renaissance State. Venice, c. 1400 to 1617 (Cambridge, 1984); Brian Pullan, Rich and Poor in Renaissance Venice (Oxford, 1971).

"Rogers Brubaker, Citizenship and Nationhood in France and Germany (Cambridge, 1992). On immigration, ethnicity and citizenship in France, the United States and elsewhere, see John Bodnar, The Transplanted. A History of Immigrants in Urban America (Bloomington, 1985); Raymond Breton, Wsevolod W. Isajiw, Warren E. Kalbach and Jeffrey G. Reitz, Ethnic Identity and Equality: Varieties of Experience in a Canadian City (Toronto, 1990); Stephen Castles and Mark J. Miller, The Age of Migration. International Population Movements in the Modern World (New York, 1993); Lucie Cheng and Edna Bonacich (eds), Labor Immigration under Capitalism. Asian Workers in the United States before World War II (Berkeley, 1984); Stanley Lieberson and Mary C. Waters, From 
State conceptions of the relationship between ethnicity or nationality and citizenship vary along two dimensions: 1 ) from exclusive to inclusive definitions of ties to relevant ethnicities and nationalities, and 2) from primordial to learned conceptions of those ties. We might schematize the variation in this way:

$\begin{array}{lll} & \text { EXCLUSIVE } & \text { INCLUSIVE } \\ \text { PRIMORDIAL } & \text { Israel } & \text { Ottoman empire } \\ \text { LEARNED } & \text { France } & \text { USA }\end{array}$

Israel gives priority, if not absolute exclusivity, to ties of mutual recognition with other Jews, which it regards as ancient and almost immutable. France allows all sorts of people to become French, but imposes a well-defined standard of Frenchness. While giving priority to Muslims, especially Muslim Turks, the Ottoman empire tolerated a wide variety of identities, never insisting (like its Turkish successor state) that all citizens conform to a single cultural model; nevertheless, it assumed for the most part that it was dealing with durable identities rooted in custom and history. Within the space defined by primordial-learned and exclusive-inclusive, contemporary states vary considerably in their criteria for citizenship.

But more than gender, descent and residence enters qualifications for citizenship. Until 1865, the United States effectively denied citizenship to slaves on the basis of their relationship to putative owners. Since the 1920s, the same United States has strongly emphasized kinship to existing residents as a basis for legal admission of immigrants to residence and work in the country, and therefore eventually to citizenship. During the twentieth century, however, all states have given great weight to a potential citizen's ties with firms and labor markets, greatly favoring immigrants and citizens who already occupied positions in economic organizations based within the receiving state and/or whose connections promised high wages and valuable skills. In addition to kinship, descent,

Many Strands. Ethnic and Racial Groups in Contemporary America (New York, 1988); Jan Lucassen, Migrant Labour in Europe, 1600-1900. The Drift to the North Sea (London, 1987); Leslie Page Moch, Moving Europeans. Migration in Western Europe since 1650 (Bloomington, 1992); Gérard Noiriel, Le creuset français. Histoire de l'immigration XIXeXXe siècles (Paris, 1988); Alejandro Portes and Rubén G. Rumbaut, Immigrant America: A Portrait (Berkeley, 1990); Ruben G. Rumbaut, "Origins and Destinies: Immigration to the United States Since World War II", Sociological Forum, 9 (1994), pp. 583-622; Robert J. Thomas, Citizenship, Gender, and Work. Social Organization of Industrial Agriculture (Berkeley, 1985); Susan Cotts Watkins (ed.), After Ellis Island. Newcomers and Natives in the 1910 Census (New York, 1994); Robin Williams, "The Sociology of Ethnic Conflicts: Comparative International Perspectives", Annual Review of Sociology, 20 (1994), pp. 4979; Virginia Yans-McLaughlin (ed.), Immigration Reconsidered. History, Sociology, and Politics (New York, 1990); Aristide Zolberg, "Labor Migration and International Economic Regimes: Bretton Woods and After", in Mary M. Kritz, Lin Lean Lim and Hania Zlotnik (eds), International Migration Systems: A Global Approach (New York, 1992). 
cultural attachment and labor force position, ties to former colonies, religious sects, political parties and military organizations have likewise sometimes figured significantly in the granting or refusal of citizenship.

Still, not all ties map with equal ease into the distinctions of citizenship. Religious solidarities, for example, generally lost their legal standing as bases of civic distinctions in Europe during the broadening of citizenship. From the late fifteenth century to the Peace of Westphalia (1648), mass expulsions and forced conversions of Jews and Muslims in Iberia, Protestant movements and religious wars in Western and Central Europe, and attacks on the papacy's secular power in Italy disrupted the previous accommodation of multiple faiths with the public dominance of weaklynational Catholic churches. From 1648 to 1789, states and churches identified with each other more strongly than before. But with the French Revolution and the expansion of citizenship, the incompatibility between inclusive definitions of political rights and religious barriers to political participation became more urgent. Even the British establishment, entrenched in a state church since Henry VIII's seizure of church property and reinforced in its position by the Protestant settlement of 1689 , conceded relatively equal citizenship rights to non-Anglicans in 1828 and 1829.

The dissolution of religious bars to citizenship did not, of course, eliminate popular or official bigotry, as the continued salience of political anti-Semitism in much of Europe demonstrates; even in France, home of the Dreyfus Case, official laicism cohabited with sometimes-virulent political anti-Semitism. ${ }^{12}$ Nor did it eliminate on-the-average religious differences in political rights and participation within propertyqualification regimes where wealth and religious affiliation correlated with each other; in the nineteenth century United Kingdom, Irish Catholics enjoyed fewer political rights because, on the average, they had less property. What became rare was the official incorporation of religious distinctions into definitions of citizenship. These days, Israel stands out from most other countries in building religious definitions directly into the rights and obligations of citizenship. ${ }^{13}$ If they have their way, however, Islamic fundamentalists will bring many more countries back into that ancient fold.

In this collection of papers on citizenship, identity and social history, all the authors are social scientists-social historians (I resist tracing a precise line between the two categories) who draw on long-term inquiries

${ }^{12}$ Pierre Birnbaum, "La France aux Français". Histoire des haines nationalistes (Paris, 1993).

${ }^{23}$ Yagil Levy, "The Military as a Mechanism of Interethnic Reproduction: The Case of Israel", Working Paper 198, Center for Studies of Social Change, New School for Social Research (1994); Yoav Peled, "Ethnic Democracy and the Legal Construction of Citizenship: Arab Citizens of the Jewish State", American Political Science Review, 86 (1992), pp. 432-443. 
to write about topics of current interest. Marc Steinberg counters the recent tendency in nineteenth-century British historiography to minimize the importance of class as a basis of collective action and of claims to citizenship; he uses the experience of British silk weavers to make general observations of how workers framed their self-identifications and demands for just treatment by the state. Bernhard Ebbinghaus (who elsewhere has written about the present and future of European labor politics) here analyzes the interaction of parties and trade unions, attributing great importance to the interplay of social cleavages and contestation concerning citizenship. Miriam Cohen and Michael Hanagan draw on a large comparison of social provision in England, France and the United States to show how varying forms of unemployment compensation entered the package of citizens' entitlements. Ann Mische takes us to contemporary Brazil, or more precisely to São Paulo, for a close look at how young people negotiate new political identities entailing different conceptions of citizenship. Brazil also preoccupies Anthony Marx, but in comparison with the United States and South Africa - the questions being how racial categories gained a quasi-official relationship to citizenship in the latter two countries, but not in Brazil, and what difference that makes to racial politics. Eiko Ikegami extends her previous work on Japanese state formation to analyze how samurai and statesmen contended with the challenge and model of Western political organization not by outright imitation but by creating an extraordinary new definition of disciplined citizenship. My own final paper uses French and European experience as the touchstone for a general discussion of how citizenship emerged as a particular kind of tie between states and their subjects, then as a collective identity, a shared experience of the state-subject tie.

In arriving at their analyses, all our authors had to bypass the standard temptations in studies of citizenship and identity: the lure of primordialism, with its presumption that currently-existing social categories bespeak long, continuous histories of shared existence; the snare of evolutionism, with its supposition that because of its adaptive superiority thick citizenship triumphs inexorably and definitively over thin citizenship or none at all; the siren call of individualism, with its invention of autonomous, decision-making actors. In varying degrees of selfconsciousness, our authors all opt for contingency, social construction and relational analysis. They see citizenship and public identities as social relations that remain incessantly open to interpretation and renegotiation:

Marc Steinberg does battle on two fronts: against T.H. Marshall's minimization of struggle in the formation of citizenship and against the phalanx of British historians who have recently rejected class analysis as practiced by E.P. Thompson. Following Thompson, Steinberg insists on class as a dynamic relation; to be working class is to interact with capitalist in one's capacity as the bearer of labor power. He argues that 
British workers not only developed a self-understanding in just such class terms, but also made demands for citizenship on the basis of class membership. In his closely-studied case of Spitalfields silk weavers during the early nineteenth century, Steinberg finds workers demanding the retention of state protection for their industry. They did not justify their demands, Steinberg points out, through the industry's contribution to national economic growth or some such utilitarian notion, but in a vocabulary of rights and obligations binding their class to the state, a vocabulary of citizenship.

In that regard, Spitalfields' workers anticipated the surprising character of Chartism, a quintessential workers' movement demanding not higher wages or shop-floor power but political rights for toilers. The labor theory of value turns out to have political implications as well as the economic implications Karl Marx later spelled out. The chief question Steinberg leaves lingering is to what extent the Spitalfields weavers who, unlike most other workers, had actually enjoyed state protection from the 1770 s to the 1820 s - constitute a special case, off the main line of British labor history.

.In a much more present-oriented analysis than Steinberg's, Bernhard Ebbinghaus deploys a large body of evidence concerning European workers' organizations to ask what accounts for the variable relations between unions and labor-oriented political parties in various European countries during the twentieth century. He is therefore examining causes, effects and trajectories in the process that Marshall saw as producing a transition from political to social citizenship, but challenging Marshall's sequential scheme.

Ebbinghaus distinguishes five patterns: laborist unionism, solidaristic unionism, segmented pluralism, polarized pluralism and inclusive "unity" unionism. He looks back into the nineteenth century for the origins of these twentieth-century patterns. An analysis whose style recalls the comparative inquiries that Stein Rokkan once conducted leads Ebbinghaus to emphasize the interplay between the sequences in which various political institutions (e.g. manhood suffrage) appeared in a given country and that country's underlying social cleavages: not only labor vs. capital, but also religious and other divisions. ${ }^{14}$ For today and tomorrow,

14 Stein Rokkan, Citizens Elections Parties. Approaches to the Comparative Study of the Processes of Development (Oslo, 1970); "Macro-Histoire et Analyse Comparative des Processus de Développement Politique: Note Introductive", unpublished report to the Journée d'études de l'Association Française de Science Politique (1974); "Une Famille de Modèles pour l'Histoire Comparée de l'Europe Occidentale", unpublished report to the Journée d'études de l'Association Française de Science Politique (1976). See also Stefan Immerfall, "Macrohistorical Models in Historical-Electoral Research: A Fresh Look at the Stein-Rokkan-Tradition", Historical Social Research, 17 (1992), pp. 103-116; Seymour Martin Lipset and Stein Rokkan (eds), Party Systems and Voter Alignments. Cross-National Perspectives (New York, 1967); Tilly, "Stein Rokkan et les Identités Politiques"; Per 
Ebbinghaus concludes that the processes he describes embedded labor unions and parties in national organization life so firmly that they are adapting only slowly to the great changes in citizenship now sweeping over Europe.

In a similar vein, Miriam Cohen and Michael Hanagan see the current shrinking of Western states as threatening the social citizenship they established during the years following World War II. A long-run Francel USA/Britain comparison allows them, like Ebbinghaus, to trace different trajectories toward welfare states. Like Steinberg, they argue that the organization of production significantly influenced both working-class demands and the sorts of citizenship that arose in different countries. Like all our other authors, they treat the specific obligations and rights of citizenship as variable, contingent outcomes of struggle.

Unlike any of the rest, however, Cohen and Hanagan attribute importance to population trends, especially immigration and emigration. For them, international migration strongly affected national labor supplies, which in turn conditioned both workers' and employers' receptiveness to alternative strategies for dealing with unemployment. For all the indebtedness of their questions to Marshall, the Cohen-Hanagan answers deny Marshall's minimization of struggle in the establishment of entitlements, not to mention his near-equation of citizenship with moral community. In effect, they make Marshall's analysis itself a contingent outcome of the very process he was analyzing - the expression of a moment when, at least in Britain, organized labor was wielding exceptional power over public policy.

Ann Mische takes us to Brazil for a doubly dense examination of youthful orientations to citizenship. Her analysis requires careful attention because she couples a close reading of previous statements about identity and collective action with thick evidence from direct immersion in the lives of São Paulo's youth movements. Adopting a strongly interactional position, she argues close correspondence among four elements that other students of social. movements have seen as only contingently connected with each other: understandings of politics and of particular groups within the political arena; projects of political transformation; public identities; and networks that link individuals and groups.

She further complicates her story by discussing the significance of what she calls bridging in all these regards. While some understandings distinguish a particular group, others span groups and facilitate their collaboration. Similarly, projects such as democratization have local variants, but in their bridging forms justify joint action. All actors deploy multiple identities, and some public identities - notably that of citizen -

Torsvik (ed.), Mobilization, Center-Periphery Structures and Nation-Building (Bergen, 1981). 
span many actors as well as their groups. Most clearly and crucially, certain individuals and groups form bridges among islands of close interpersonal collaboration, thus becoming bearers, initiators and transformers of understandings, projects and identities. Because both the social base and the external relations of each type of local youth group varies systematically from sector to sector, the network structures of the major sectors - she distinguishes political cadres, grass roots movements, civic institutions, and technical experts - differ dramatically. So, accordingly, do their shared conceptions of citizenship.

Anthony Marx offers us an analysis of race as a political and social identity in Brazil, the United States and South Africa. In addition to a telling critique of previous attempts to account for international differences in race relations, his paper provides two significant explanatory efforts. First, he makes a case for state ratification of racial categories as a basis of a more general racially-divided politics. Second, he argues a connection between racially-defined mobilizations and changes in state policies. Then he links the two by insisting on an irony: a state's establishment of legally-supported racial categories, although discriminatory, facilitates later mobilization against racial discrimination.

Marx does not claim that race relations are "better" in Brazil because the state is color-blind; indeed, the absence of official categories leaves wide racial inequalities in well-being unattended to and inaccessible to state policy. He does claim that state creation or incorporation of racial labels, while commonly begun in the interest of organized repression, has the long-term effect of legitimating and facilitating mobilization along racial lines. (Note the similarities to Chartism, where within six years after 1832 the principled exclusion of the politically-mobilized working class by the Reform Bill had spurred a massive new working-class mobilization on behalf of political rights.) The analysis matters not only in itself but also in the parallels with other politically-generated or politically-ratified categories such as ethnic group, nation, citizen or, for that matter, pauper.

What remains least clear in Marx's analysis - not to mention all the others in this volume - remains unclear in most such analyses: exactly what connection exists between the political mobilization of one identity or another and the embedding of everyday social relations in related identities? To what extent and how, for example, does the radical segregation of work, labor markets, housing, kinship, sociability and sexuality promote mobilization within the same divisions? The answer to that much-debated question will have strong implications for Bosnia, Abkhazia and Somalia as well as for Brazil, the United States and South Africa.

At first glance, Eiko Ikegami seems to be addressing a rather different set of questions: how did Japan make its transition from the relatively segmented political structure of Tokugawa to the rather centralized 
institutions of Meiji? How did the Japanese state form citizens out of subjects it had long held at a distance from its centers of power? She is actually exploring the creation of citizenship. She uses Western European experience knowledgeably as a point of reference without making it a universal model. Like Mische, furthermore, she calls attention to the creation of new vocabularies to articulate new forms of citizenship.

Ikegami argues, in essence, that energetic, clairvoyant samurai, faced with the collapse of the Tokugawa state's repressive and military capacity under pressure from the West; had powerful incentives to create a stronger, more centralized, bureaucratized, militarily effective state, but could not do so without extensive popular support that was not available under the segmented old regime with its disarmed peasantry and segregated samurai. Understanding their problem and looking westward for organizational models, some of the samurai more or less deliberately promoted a rapid passage through an equivalent of the struggle and bargaining over means of state power that had created effective citizenship in Western Europe. They also enlisted ambitious non-samurai in their meritocratic state-centered project.

Very well, we might say, but given the way Europeans bloodied and blundered their ways to citizenship and centralized statehood, why in the world did the process run as intended in Japan? Did Japanese elites simply invent and impose appropriate public identities on their citizens? If so, why didn't something similar happen in the ruins of the Habsburg and Ottoman empires? Why isn't it happening in the former Soviet Union today? Have we returned to national character - Japanese national character - after all?

The answer, of course, is no. Like her colleagues, Ikegami has set herself firmly against essentialist accounts of political behavior and toward understandings of politics as contingent, negotiated and interactive. My own final paper on the formation of thick citizenship moves in precisely the same direction. Using France as a springboard, I leap into the history of state formation, with special reference to military service as a forcefully-imposed obligation of male citizens. My paper identifies connections between the thickening of citizenship and the growth of different forms of nationalism, as well as specifying relations between citizenship and democracy. It closes with warnings against taking the Western European pattern as the universal model for citizenship, and with questions - not answers - concerning the future of citizenship in an age of changing states.

Individually and collectively, the papers fail to tell us why people will kill each other over competing national claims to territory in the Balkans, whether citizenship in a united Europe will crowd out citizenship in its component states, what is driving Germany toward more restrictive definitions of citizenship, under what conditions African countries can move away from military rule toward unity and democracy, whether the 
USA will continue to expel Haitians and Mexicans while welcoming Cubans, and so on through many of the questions readers of today's headlines might reasonably ask of experts on citizenship and identity. Nor should they have tried. If this collection sheds no light on such issues, to be sure, we will be sorely disappointed. But the main work at hand puts them in context. It seeks keys to variation and change in the character of political identities and definitions of citizenship. For headline-readers, it provides indispensable opportunities for analogies and contrasts. For analysts of political processes in general, it brings systematic thinking to bear on real cases of contested, changing identity. 